University of Nebraska - Lincoln

DigitalCommons@University of Nebraska - Lincoln

Agronomy \& Horticulture -- Faculty Publications

Agronomy and Horticulture Department

2011

\title{
Switchgrass for forage and bioenergy: Harvest and nitrogen rate effects on biomass yields and nutrient composition
}

John A. Guretzky

University of Nebraska-Lincoln, jguretzky2@unl.edu

Jon T. Biermacher

The Samuel Roberts Noble Foundation, Ardmore, OK, jtbiermacher@noble.org

Billy Cook

The Samuel Roberts Noble Foundation, Ardmore, OK, bjcook@noble.org

Maru K. Kering

Samuel Roberts Noble Foundation, mkkering@noble.org

Jagadeesh Mosali

Samuel Roberts Noble Foundation, Ardmore, OK, jmosali@noble.org

Follow this and additional works at: https://digitalcommons.unl.edu/agronomyfacpub

Part of the Plant Sciences Commons

Guretzky, John A.; Biermacher, Jon T.; Cook, Billy; Kering, Maru K.; and Mosali, Jagadeesh, "Switchgrass for forage and bioenergy: Harvest and nitrogen rate effects on biomass yields and nutrient composition" (2011). Agronomy \& Horticulture -- Faculty Publications. 556.

https://digitalcommons.unl.edu/agronomyfacpub/556

This Article is brought to you for free and open access by the Agronomy and Horticulture Department at DigitalCommons@University of Nebraska - Lincoln. It has been accepted for inclusion in Agronomy \& Horticulture -Faculty Publications by an authorized administrator of DigitalCommons@University of Nebraska - Lincoln. 
Published in Plant and Soil: An International Journal on Plant-Soil Relationships 339 (2011), pp. 69-81; doi: 10.1007/s11104-010-0376-4

Copyright (C) 2010 Springer Science+Business Media B.V. Used by permission.

Submitted October 30, 2009; accepted March 31, 2010; published online April 15, 2010

\title{
Switchgrass for forage and bioenergy: Harvest and nitrogen rate effects on biomass yields and nutrient composition
}

\author{
John A. Guretzky, ${ }^{1}$ Jon T. Biermacher, ${ }^{2}$ Billy J. Cook, ${ }^{2}$ \\ Maru K. Kering, ${ }^{2}$ and Jagadeesh Mosali ${ }^{2}$ \\ 1. Department of Agronomy and Horticulture, University of Nebraska-Lincoln, Lincoln, Nebraska 68583-0915, USA \\ 2. Agricultural Division, The Samuel Roberts Noble Foundation, Ardmore, Oklahoma 73401, USA \\ Corresponding author - John A. Guretzky, email jguretzky2@unl.edu
}

\begin{abstract}
Switchgrass (Panicum virgatum L.) may have value as forage and a bioenergy feedstock. Our objective was to evaluate how harvest system and $\mathrm{N}$ fertilizer rates affected biomass yield and nutrient composition of young stands of switchgrass (cv. Alamo) in the southern Great Plains, USA. Nitrogen fertilization increased biomass yields from 10.4, 10.8, and $12.2 \mathrm{Mg} \mathrm{ha}^{-1}$ at $0 \mathrm{~kg} \mathrm{~N} \mathrm{ha}^{-1}$ to $13.7,14.6$, and $21.0 \mathrm{Mg} \mathrm{ha}^{-1}$ at $225 \mathrm{~kg} \mathrm{~N} \mathrm{ha}^{-1}$ when harvested after seed set (October), after frost (December), and twice per year after boot stage (July) and frost, respectively. Nutrient concentrations and removal were generally twice as great when biomass was harvested twice versus once per year. Precipitation strongly affected biomass yields across the two years of these experiments. When late-summer precipitation is available to support regrowth in this environment, harvesting switchgrass twice per year will result in greater biomass yields. Harvesting twice per year, however, will increase fertilization requirements and reduce feedstock biomass quality. Switchgrass harvested during mid-summer after boot stage was of poor forage quality. To have value as a dual-purpose forage and bioenergy feedstock, switchgrass would need to be utilized during spring to early summer while in a vegetative stage.
\end{abstract}

Keywords: biofuels, biomass quality, cellulosic feedstock production, ethanol, forage quality

Abbreviations: $\mathrm{ADF}=$ Acid detergent fiber; $\mathrm{CRP}=$ Conservation Reserve Program; IVDMD $=$ In vitro dry matter digestibility; NIRS = Near infrared reflectance spectroscopy; NDF = Neutral detergent fiber

\section{Introduction}

Public interest in substitution of petroleumbased transportation fuels with biofuels has increased the last several years as prices of crude oil and natural gas, instability in oil producing countries, and concerns about climate change have soared. In the United States, ethanol produced from grain constitutes $99 \%$ of biofuels used today (Farrell et al. 2006; CAST 2007). Grain ethanol production requires far less petroleum but generates similar levels of greenhouse gas emissions as production of gasoline (Farrell et al. 2006). Future biofuel systems are expected to depend more 
heavily on processing and conversion of cellulosic or biomass-based feedstocks to ethanol (Farrell et al. 2006; CAST 2007). Although still evolving as a technology, cellulosic ethanol production has potential to dramatically reduce greenhouse gas emissions (Farrell et al. 2006; Schmer et al. 2008; Varvel et al. 2008). To aid unimpeded transition to widespread adoption of renewable fuels, the United States Congress passed the Energy Independence and Security Act in 2007. The act increased the Renewable Fuel Standard (RFS) in the United States to 136 billion L by 2022; of which, 60 billion L of ethanol were to be produced from cellulosic biomass feedstocks (Biomass Research and Development Board 2008).

Switchgrass (Panicum virgatum L.), a $\mathrm{C}_{4}$-grass indigenous to North America, has been identified as a primary next-generation cellulosic feedstock. Desirable traits include its high biomass yield potential, adaptability to marginal soil, and perennial growth habit (McLaughlin and Kszos 2005). Research sponsored by the U.S. Department of Energy (DOE) in the 1990's led to heightenedbreeding programs and the subsequent release of new varieties and identification of best management practices for producing and maintaining switchgrass as a biomass energy crop (McLaughlin and Kszos 2005). Biomass yields of switchgrass strongly depend on origin and ecotype of cultivars and fertilizer and harvest management practices. In general, cultivars selected from plant materials originating from northern latitudes flower earlier, yield less, and have a longer winter dormant period than cultivars derived from southern latitudes when grown in the same environment (Cassida et al. 2005; Parrish et al. 2008). Lowland ecotypes of switchgrass tend to have bunch-type growth forms, thicker stems, shorter rhizomes, and more biomass production than upland ecotypes (Cassida et al. 2005; Parrish et al. 2008). Maximum biomass yields of switchgrass have been obtained with $\mathrm{N}$ fertilizer rates ranging from 0 to $168 \mathrm{~kg} \mathrm{ha}^{-1}$, depending on cultivar, age of stand, and harvest system (Muir et al. 2001; Sanderson et al. 1999; Vogel et al. 2002). Several research studies support harvesting of switchgrass once per year after frost to allow for maximal translocation of nutrients and building of storage reserves in roots before harvest (Muir et al. 2001; Sanderson et al. 1999; Vogel et al. 2002).
Despite earlier research efforts, challenges to feedstock production remain (Bransby et al. 2008). Growers need incentives and information on how best to incorporate cellulosic feedstock enterprises within their farm's current mix of food, feed, or fiber enterprises (CAST 2007). In the Great Plains region of the central United States, beef cattle production is a major agricultural enterprise. While the region has been identified as promising for cellulosic feedstock production (Schmer et al. 2008), the region currently holds an inventory of more than 31 million head of cattle (USDA-NASS 2008). Identification of management practices that allow for use of switchgrass as a forage and an energy crop may facilitate earlier adoption of switchgrass within this regional enterprise. Important to sustainability of switchgrass as a forage and energy crop is definition of how management practices affect biomass supply, nutrient composition, and nutrient removal (Fixen 2007).

Livestock and biofuel production enterprises have different biomass quality requirements. High concentrations of crude protein ( $\mathrm{N}$ content $\times$ a correction factor) and digestible dry matter are desired in forage. Neutral detergent fiber (NDF) and acid detergent fiber (ADF), which provide estimates of cell wall constituents cellulose, hemicellulose, and lignin, are negatively correlated with intake and digestibility in ruminants (Ball et al. 2001). Quality of plant biomass for biofuels depends on whether conversion systems use biochemical, thermochemical, or direct combustion processes (Adler et al. 2006; Sanderson et al. 2007). For direct combustion and thermochemical conversion systems, reduced mineral element concentrations are desirable. Harvesting at later maturity stages reduces mineral nutrient concentrations and increases lignin contents of biomass. Lignin contributes energy during the thermochemical conversion process, but it also binds with cellulose and hemicellulose, reducing their availability and ethanol yields during the biochemical conversion process (Adler et al. 2006; Sanderson et al. 2007).

To evaluate how management affects switchgrass as a forage and an energy crop in the southern Great Plains, we conducted experiments at two Oklahoma locations in 2008 and 2009. Our objective was to evaluate effects of location, harvest system, $\mathrm{N}$ fertilizer rates, and year on switchgrass biomass yields, nutrient concentrations, and nutrient 
removal rates. Research was initiated on one-yr old stands of a southern lowland-type of switchgrass (cv. Alamo) established at each location in 2007. Our hypothesis was that harvesting of switchgrass at a late-boot stage would provide high-quality forage for livestock but would increase fertilization requirements. Greater biomass yields and lower nutrient removal rates were expected with biomass harvests conducted once per year after frost relative to harvests conducted during the growing season.

\section{Materials and methods}

Harvest system-by-nitrogen fertilizer rate experiments were initiated in the spring of 2008 in 1-yr old stands of switchgrass at Varner Farms in Tillman County near Frederick, Oklahoma (34 $23^{\prime} \mathrm{N}$; $98^{\circ} 85^{\prime} \mathrm{W}$ ) and at the Noble Foundation Red River Farm in Love County near Burneyville, Oklahoma $\left(33^{\circ} 89^{\prime} \mathrm{N} ; 9^{\circ} 7^{\circ} 29^{\prime} \mathrm{W}\right)$. Alamo switchgrass was established in clean-tilled soils using an SS-series agricultural seeder (Brillion Farm Equipment, Brillion, WI, USA) in a 2-ha block at Frederick and a 12-ha block at Burneyville in May 2007 (Table 1). Treatments applied to $6.1 \times 7.6 \mathrm{~m}$ plots in 2008 and 2009 included six $\mathrm{N}$ fertilizer rates $(0,45,90,135$, 180 , and $225 \mathrm{~kg} \mathrm{ha}^{-1}$ ) applied as ammonium nitrate in spring and three harvest systems. Harvest systems included harvesting once per year after seed set; once per year after frost; and twice per year after boot-stage and after frost (Table 1). The experiments were randomized complete block designs with a split-plot arrangement of treatments and four replications. Harvest systems were main plots and $\mathrm{N}$ rates were subplots.

Soil types were a Foard silt loam (fine, smectitic, thermic Vertic Natrustolls) at Frederick and a Minco fine sandy loam (coarse-silty, mixed, superactive, thermic Udic Haplustolls) at Burneyville. Before this research, the fields were used for production of cotton (Gossypium spp. L.) at Frederick and rye (Secale cereale L.) pasture at Burneyville. Soil samples were collected from 0 - to 15- and 15- to 30-cm depths in April 2007 at Frederick and from 0- to 15-cm depths in March 2008 at Burneyville and analyzed for $\mathrm{pH}$ at a 1:1 soil to water ratio (Lierop 1990), organic matter by high temperature combustion (Nelson and Sommers 1982), P by the Mehlich-3 procedure (Fixen and Grove 1990), and K via ammonium acetate extraction (Haby et al. 1990). Soils had $8.2 \mathrm{pH}, 1.9 \%$ to
$2.4 \%$ organic matter, 8 to $56 \mathrm{mg} \mathrm{P} \mathrm{kg}^{-1}$, and 306 to $530 \mathrm{mg} \mathrm{K} \mathrm{kg}^{-1}$ at Frederick and $6.6 \mathrm{pH}, 1.0 \%$ organic matter, $33 \mathrm{mg} \mathrm{P} \mathrm{kg}{ }^{-1}$, and $172 \mathrm{mg} \mathrm{K} \mathrm{kg}{ }^{-1}$ at Burneyville. Phosphorus and $\mathrm{K}$ were applied across all plots in 2008 and 2009 within blanket applications of triple superphosphate (0-46-0) at $67.2 \mathrm{~kg} \mathrm{ha}^{-1}$ (14 kg P ha-1) and potassium chloride $(0-0-60)$ at $134 \mathrm{~kg} \mathrm{ha}^{-1}\left(60 \mathrm{~kg} \mathrm{~K} \mathrm{ha}^{-1}\right)$ so as to not deplete these nutrients within the one harvest after frost system in time. Fertilizer was not applied during the establishment year.

Biomass was harvested according to treatment schedule in 2008 and 2009 with either a Carter forage harvester or a HEGE forage plot harvester at a $10-\mathrm{cm}$ height. Subsamples of the harvested biomass were collected for dry matter determination and forage nutrient analysis. Following drying at $60^{\circ} \mathrm{C}$, samples were ground to pass a $<1 \mathrm{~mm}$ screen using a Wiley Mill (Thomas Scientific, Swedesboro, NJ) and prepared for nutrient analysis. Nutrient concentrations were estimated with near infrared spectroscopy (NIRS) analysis (Shenk and Westerhaus 1994) using equations developed by the NIRS Forage and Feed Testing Consortium (Table 2) and included dry matter, N, P, K, NDF, ADF, and in vitro dry matter digestibility (IVDMD), a laboratory bioassay that estimates the proportion of dry matter in forage digestible by a ruminant (Ball et al. 2001).

Analysis of variance was conducted using the mixed models procedure in SAS to determine main effects and interactions of location, harvest system, and $\mathrm{N}$ fertilizer rate. Location, harvest system, and $\mathrm{N}$ rate were considered fixed effects. Years and replications were considered random effects. The statistical models applied the autoregressive (AR1) spatial power covariance structure to help account for temporal autocorrelation in data collected across growing periods. Individual field plots were utilized as local subjects within all analyses, as they represented the units in the study that received the specified fertilizer and harvest management treatments over the course of the study.

\section{Results}

\section{Year effects}

Long-term yearly precipitation (1971-2000) was less at Frederick than at Burneyville, averaging 78 
Table 1. Timing of field operations and management activities for switchgrass grown within harvest system and $\mathrm{N}$ fertilizer rate experiments at Frederick and Burneyville, Oklahoma, USA, from 2008 to 2009

\begin{tabular}{|c|c|c|c|}
\hline \multirow[t]{2}{*}{ Year } & \multirow[b]{2}{*}{ Field operation } & \multicolumn{2}{|l|}{ Location } \\
\hline & & Frederick & Burneyville \\
\hline \multirow[t]{6}{*}{2007} & Glyphosate applications & None & 7 May \\
\hline & Field discing & None & 21 May \\
\hline & Field cultivation & 19 May & 21 May \\
\hline & Brillion broadcast seeding & 21 May & 22 May \\
\hline & Mowing to cut down weeds & None & 19 July \\
\hline & 2,4-D amine applications & None & 19 July \\
\hline \multirow[t]{8}{*}{2008} & $\mathrm{P}$ and $\mathrm{K}$ applications & 4 April & 9 April \\
\hline & Last spring killing freeze & $24 \operatorname{March}\left(-2^{\circ} \mathrm{C}\right)$ & $24 \operatorname{March}\left(-3^{\circ} \mathrm{C}\right)$ \\
\hline & Herbicide applications & None & None \\
\hline & $\mathrm{N}$ treatment applications & 4 April & 9 April \\
\hline & After boot stage harvests & 16 July & 11 July \\
\hline & After seed set harvests & 10 October & 14 October \\
\hline & First fall killing freeze & 21 November $\left(-6^{\circ} \mathrm{C}\right)$ & 28 October $\left(-4^{\circ} \mathrm{C}\right)$ \\
\hline & After frost harvests & 12 December & 19 December \\
\hline \multirow[t]{8}{*}{2009} & $\mathrm{P}$ and $\mathrm{K}$ applications & 13 March & 3 March \\
\hline & Last spring killing freeze & 7 April $\left(-6^{\circ} \mathrm{C}\right)$ & 7 April $\left(-7^{\circ} \mathrm{C}\right)$ \\
\hline & 2,4-D amine applications & None & 7 April \\
\hline & $\mathrm{N}$ treatment applications & 13 March & 6 March \\
\hline & After boot stage harvests & 14 August & 16 July \\
\hline & After seed set harvests & 5 November & 2 November \\
\hline & First fall killing freeze & 3 December $\left(-3^{\circ} \mathrm{C}\right)$ & 26 November $\left(-3^{\circ} \mathrm{C}\right)$ \\
\hline & After frost harvests & 11 January & 14 December \\
\hline
\end{tabular}

and $99 \mathrm{~cm}$, respectively (Oklahoma Climatological Survey 2009). Precipitation was $26 \%$ to $41 \%$ below these long-term averages in 2008 but $17 \%$ to $31 \%$ above these long-term averages in 2009 (Table 3). June, July, and September were particularly dry months at each location in 2008. In 2009, all months throughout the growing season (April through October) had significant precipitation. A wet July caused a one-month delay in the after boot stage harvest at Frederick until 14 August (Table 1). A wet September and October caused delays in the after seed set harvests at both locations until early November (Table 1). Monthly and annual temperatures were similar to long-term average monthly and annual temperatures at each location (Table 3).

Accompanying the impressive 33- to $72-\mathrm{cm}$ gain in precipitation from 2008 to 2009 across the locations were strong biomass yield increases (Table 4). On average across locations, harvest systems, N rates, and replications, biomass yield increased by 
Table 3. Average monthly and yearly temperatures and precipitation from 2008 to 2009 and average (avg) long-term (1971-2000) temperatures and precipitation at Frederick and Burneyville, OK, USA

\begin{tabular}{|c|c|c|c|c|c|c|c|c|c|c|c|c|c|c|}
\hline Location & Year & $\begin{array}{l}\text { Mor } \\
\text { Jan }\end{array}$ & $\mathrm{Feb}$ & Mar & Apr & May & Jun & Jul & Aug & Sep & Oct & Nov & Dec & Avg/Tot \\
\hline \multicolumn{15}{|c|}{ Temperature, ${ }^{\circ} \mathrm{C}$} \\
\hline \multirow[t]{3}{*}{ Frederick } & 2008 & 5 & 7 & 12 & 16 & 23 & 29 & 30 & 28 & 23 & 17 & 11 & 5 & $17^{a}$ \\
\hline & 2009 & 4 & 10 & 13 & 17 & 20 & 28 & 29 & 29 & 23 & 14 & 12 & 2 & 17 \\
\hline & Avg & 4 & 7 & 12 & 17 & 22 & 26 & 29 & 28 & 24 & 18 & 11 & 5 & 17 \\
\hline \multirow[t]{3}{*}{ Burneyville } & 2008 & 5 & 8 & 13 & 17 & 22 & 27 & 29 & 27 & 22 & 18 & 12 & 6 & 17 \\
\hline & 2009 & 5 & 11 & 14 & 17 & 20 & 27 & 28 & 27 & 22 & 15 & 13 & 3 & 17 \\
\hline & Avg & 5 & 8 & 13 & 17 & 22 & 26 & 29 & 28 & 24 & 19 & 12 & 7 & 17 \\
\hline \multicolumn{15}{|c|}{ Precipitation, $\mathrm{cm}$} \\
\hline \multirow[t]{3}{*}{ Frederick } & 2008 & 0 & 3 & 5 & 8 & 9 & 5 & 3 & 15 & 2 & 6 & 1 & 1 & $58^{b}$ \\
\hline & 2009 & 2 & 1 & 1 & 18 & 11 & 9 & 13 & 4 & 12 & 11 & 0 & 8 & 91 \\
\hline & Avg & 3 & 4 & 6 & 7 & 12 & 10 & 5 & 7 & 8 & 8 & 4 & 3 & 79 \\
\hline \multirow[t]{3}{*}{ Burneyville } & 2008 & 0 & 3 & 14 & 6 & 9 & 6 & 1 & 9 & 4 & 3 & 1 & 1 & 58 \\
\hline & 2009 & 1 & 4 & 5 & 39 & 12 & 6 & 8 & 6 & 18 & 20 & 1 & 9 & 130 \\
\hline & Avg & 4 & 5 & 8 & 9 & 13 & 11 & 6 & 7 & 10 & 11 & 7 & 6 & 98 \\
\hline
\end{tabular}

a. Average annual temperatures

b. Total annual precipitation

$50 \%$ from 2008 to 2009 ( $p<0.001)$. Increases in biomass yield within the one cut after seed set and the two cut per year system largely accounted for the overall biomass yield increase from 2008 to 2009 . These systems had biomass yield increases of $61 \%$ to $77 \%$ from 2008 to 2009 . The biomass yield increase from 2008 to 2009 was greater yet for harvests conducted after boot stage within the two cut per year system. Biomass yield of harvests after boot stage averaged $19.6 \mathrm{Mg} \mathrm{ha}^{-1}$ in 2009 compared to $9.8 \mathrm{Mg} \mathrm{ha}^{-1}$ in $2008(p<0.001$; SE $=0.74)$. In contrast, biomass yield of regrowth harvested after frost was less in 2009 than in 2008, averaging 2.6 and $3.9 \mathrm{Mg} \mathrm{ha}^{-1}$, respectively $(p<0.01 ; \mathrm{SE}=0.32)$. The large increase in biomass yields from harvests after boot stage and after seed set were due in part to the rain- delayed harvests in 2009 relative to 2008 (Table 1).

Reflecting precipitation and biomass yield increases were greater nutrient removal rates and altered biomass nutrient and fiber concentrations from 2008 to 2009 (Table 4). Nitrogen, P, and K removal increased by $22 \%, 67 \%$, and $89 \%$ from 2008 to 2009 , respectively $(p<0.001)$. Concentration of $\mathrm{N}$ in biomass decreased by $21 \%$ from 2008 to 2009 $(p<0.05)$. Whereas, concentration of $\mathrm{P}$ and $\mathrm{K}$ increased by $10 \%$ to $22 \%$ from 2008 to 2009 ( $p<0.05$ and $p<0.001$, respectively). Concentrations of
NDF and ADF increased by $1 \%$ to $6 \%$ and IVDMD decreased by $6 \%$ from 2008 to 2009 ( $p<0.001)$.

\section{Location and harvest system effects}

Location affected biomass nutrient concentrations but had limited effects on biomass yield (Table 5). Across harvest systems, $\mathrm{N}$ rates, years, and replications, biomass yield was similar among locations, averaging $14.9 \mathrm{Mg} \mathrm{ha}^{-1}(p=0.232)$. Concentrations and removal rates of $\mathrm{N}$ in biomass, however, were $54 \%$ and $67 \%$ greater at Burneyville than at Frederick, respectively $(p<0.001)$. Phosphorus and $\mathrm{K}$ removal rates were similar among locations $(p>0.10)$ despite a $22 \%$ greater concentration of $\mathrm{K}$ in biomass at Frederick than at Burneyville $(p<0.001)$. Concentrations of NDF and ADF were $2 \%$ to $5 \%$ greater and IVDMD was $11 \%$ less at Burneyville than at Frederick $(p<0.001)$.

Harvesting switchgrass two times per year after boot stage and after a killing frost increased concentration of nutrients in biomass, nutrient removal rates, and biomass yield (Table 5). Across locations, $\mathrm{N}$ rates, years, and replications, biomass yield averaged 13.6, 13.0, and $18.0 \mathrm{Mg} \mathrm{ha}^{-1}$ within the one harvest after seed set, one harvest after frost, and two harvests per year systems, respectively $(p<0.001)$. Harvesting switchgrass twice per 
Table 4. Year effects on biomass yield, nutrient concentrations, and nutrient removal from switchgrass harvested either once per year after seed production, once per year after frost, or twice per year after boot-stage and after frost at Frederick and Burneyville, Oklahoma, USA

\begin{tabular}{|c|c|c|c|c|c|c|c|}
\hline \multirow[t]{2}{*}{ Parameter } & \multirow[t]{2}{*}{ Units } & \multirow[t]{2}{*}{ Year } & \multicolumn{5}{|c|}{ Harvest system } \\
\hline & & & After seed set & After frost & Twice & Mean & $\mathrm{SE}$ \\
\hline \multirow[t]{2}{*}{ Yield } & \multirow[t]{2}{*}{$\mathrm{mg} \mathrm{ha}^{-1}$} & 2008 & 9.8 & 12.1 & 13.8 & 11.9 & $0.72^{\mathrm{a}}$ \\
\hline & & 2009 & 17.4 & 14.0 & 22.2 & 17.9 & $0.51^{b}$ \\
\hline \multirow[t]{2}{*}{ N uptake } & \multirow[t]{2}{*}{$\mathrm{kg} \mathrm{ha}^{-1}$} & 2008 & 67 & 94 & 152 & 104 & 7.1 \\
\hline & & 2009 & 108 & 81 & 192 & 127 & 5.1 \\
\hline \multirow[t]{2}{*}{ P uptake } & \multirow[t]{2}{*}{$\mathrm{kg} \mathrm{ha}^{-1}$} & 2008 & 10 & 9 & 18 & 12 & 0.7 \\
\hline & & 2009 & 19 & 13 & 29 & 20 & 0.5 \\
\hline \multirow[t]{2}{*}{ K uptake } & \multirow{2}{*}{$\mathrm{kg} \mathrm{ha}^{-1}$} & 2008 & 56 & 30 & 164 & 84 & 8.0 \\
\hline & & 2009 & 127 & 80 & 270 & 159 & 4.6 \\
\hline \multirow[t]{2}{*}{$\mathrm{N}$} & \multirow[t]{2}{*}{$\mathrm{g} \mathrm{kg}^{-1}$} & 2008 & 6.9 & 7.7 & 10.5 & 8.4 & 0.47 \\
\hline & & 2009 & 6.1 & 5.3 & 8.5 & 6.6 & 0.32 \\
\hline \multirow[t]{2}{*}{$\mathrm{P}$} & \multirow[t]{2}{*}{$\mathrm{g} \mathrm{kg}^{-1}$} & 2008 & 1.1 & 0.7 & 1.3 & 1.0 & 0.03 \\
\hline & & 2009 & 1.1 & 0.9 & 1.3 & 1.1 & 0.02 \\
\hline \multirow[t]{2}{*}{ K } & \multirow[t]{2}{*}{$\mathrm{g} \mathrm{kg}^{-1}$} & 2008 & 5.8 & 2.6 & 12.2 & 6.9 & 0.37 \\
\hline & & 2009 & 7.3 & 5.7 & 12.2 & 8.4 & 0.22 \\
\hline \multirow[t]{2}{*}{ NDF } & \multirow[t]{2}{*}{$\mathrm{g} \mathrm{kg}^{-1}$} & 2008 & 809 & 826 & 740 & 792 & 5.8 \\
\hline & & 2009 & 802 & 851 & 752 & 801 & 3.3 \\
\hline \multirow[t]{2}{*}{$\mathrm{ADF}$} & \multirow[t]{2}{*}{$\mathrm{g} \mathrm{kg}^{-1}$} & 2008 & 474 & 494 & 426 & 465 & 4.8 \\
\hline & & 2009 & 496 & 525 & 455 & 492 & 3.5 \\
\hline \multirow[t]{2}{*}{$\mathrm{IVDMD}^{\mathrm{c}}$} & \multirow[t]{2}{*}{$\mathrm{g} \mathrm{kg}^{-1}$} & 2008 & 477 & 480 & 589 & 515 & 8.0 \\
\hline & & 2009 & 479 & 415 & 553 & 482 & 4.6 \\
\hline
\end{tabular}

a. Standard error for comparisons of means by harvest system and year $(n=48)$

b. Standard error for comparisons of means by year $(n=144)$

c. In vitro dry matter digestibility year essentially doubled the amount of $\mathrm{N}, \mathrm{P}$, and $\mathrm{K}$ removed compared to harvesting once per year $(p<0.001)$. Biomass contained 6.5 and $9.5 \mathrm{~g} \mathrm{~N} \mathrm{~kg}^{-1}$, 1.0 and $1.3 \mathrm{~g} \mathrm{P} \mathrm{kg}^{-1}$, and 5.4 and $12.2 \mathrm{~g} \mathrm{~K} \mathrm{~kg}^{-1}$ within the one and two harvests per year systems, respectively $(p<0.001)$.

Harvesting once per year after frost reduced $P$ and $\mathrm{K}$ and increased fiber concentrations in biomass relative to harvesting once per year after seed set (Table 5). Biomass contained 1.1 and $0.8 \mathrm{~g} \mathrm{P}$ $\mathrm{kg}^{-1}$ and 6.6 and $4.2 \mathrm{~g} \mathrm{~K} \mathrm{~kg}^{-1}$ within the one harvest after seed set and one harvest after frost systems, respectively $(p<0.001)$. Neutral detergent fiber averaged 806, 839, and $746 \mathrm{~g} \mathrm{~kg}^{-1}$ within the one harvest after seed set, one harvest after frost, and two harvests per year systems, respectively $(p<0.001)$. Acid detergent fiber averaged 485, 510, and $440 \mathrm{~g} \mathrm{~kg}^{-1}(p<0.001)$ and IVDMD averaged 478,447 , and $560 \mathrm{~g} \mathrm{~kg}^{-1}(p<0.001)$ across these systems, respectively.

The nutrients removed within the two harvests per year system largely were obtained from the harvest after boot stage (Table 6). Across locations, $\mathrm{N}$ rates, and replications, biomass yield averaged
14.7 and $3.3 \mathrm{Mg} \mathrm{ha}^{-1}$ within the after boot stage and after frost harvests, respectively. Biomass yield was similar among locations within the after boot stage harvests $(p=0.44)$ but greater at Burneyville than at Frederick during the after frost harvests $(p<0.001)$. Nitrogen removal rates during the boot stage harvests exceeded those within the after frost harvests by $95 \mathrm{~kg} \mathrm{ha}^{-1}$ despite a greater concentration of $\mathrm{N}$ in biomass harvested after frost than at boot stage (Table 6). Concentrations and removal rates of $\mathrm{P}$ and $\mathrm{K}$ within the after boot stage harvests greatly exceeded those of the after frost harvests. Concentrations of NDF and ADF were greater and IVDMD was less within the regrowth harvested after frost than within the harvest after boot stage.

\section{Interactions of location, harvest system, and year}

Interactions of location, harvest system, and year affected biomass yields, nutrient concentrations, and nutrient removal rates to some degree $(p<0.001$; data not shown). The interactions appeared to result from the rain-delayed harvests and accompanying large increases in biomass yield 
Table 5. Location and harvest system effects on biomass yield, nutrient removal, and nutrient concentrations in switchgrass harvested once per year after seed set, once per year after frost, or twice per year after boot-stage and frost at Frederick and Burneyville, Oklahoma, USA, from 2008 to 2009

\begin{tabular}{|c|c|c|c|c|c|c|c|}
\hline \multirow[t]{2}{*}{ Parameter } & \multirow[t]{2}{*}{ Units } & \multirow[t]{2}{*}{ Location } & \multicolumn{5}{|l|}{ Harvest system } \\
\hline & & & After seed set & After frost & Twice & Mean & SE \\
\hline \multirow[t]{3}{*}{ Yield } & \multirow[t]{3}{*}{$\mathrm{Mg} \mathrm{ha}^{-1}$} & Frederick & 14.2 & 11.7 & 16.7 & 14.3 & $0.87^{\mathrm{a}}$ \\
\hline & & Burneyville & 13.1 & 14.4 & 19.0 & 15.5 & $0.60^{\mathrm{b}}$ \\
\hline & & Mean & 13.6 & 13.0 & 18.0 & 14.9 & $0.62^{c}$ \\
\hline \multirow[t]{3}{*}{$\mathrm{N}$ removal } & \multirow[t]{3}{*}{$\mathrm{kg} \mathrm{ha}^{-1}$} & Frederick & 75 & 63 & 122 & 86 & 8.4 \\
\hline & & Burneyville & 100 & 112 & 222 & 144 & 5.5 \\
\hline & & Mean & 88 & 88 & 172 & 115 & 5.5 \\
\hline \multirow[t]{3}{*}{ P removal } & \multirow[t]{3}{*}{$\mathrm{kg} \mathrm{ha}^{-1}$} & Frederick & 15 & 9 & 23 & 16 & 0.8 \\
\hline & & Burneyville & 14 & 13 & 24 & 17 & 0.6 \\
\hline & & Mean & 15 & 11 & 23 & 17 & 0.5 \\
\hline \multirow[t]{3}{*}{ K removal } & \multirow[t]{3}{*}{$\mathrm{kg} \mathrm{ha}^{-1}$} & Frederick & 105 & 55 & 221 & 127 & 9.4 \\
\hline & & Burneyville & 77 & 55 & 213 & 115 & 5.3 \\
\hline & & Mean & 92 & 55 & 217 & 121 & 6.6 \\
\hline \multirow[t]{3}{*}{$\mathrm{N}$} & \multirow[t]{3}{*}{$\mathrm{g} \mathrm{kg}^{-1}$} & Frederick & 5.1 & 5.4 & 7.2 & 5.9 & 0.48 \\
\hline & & Burneyville & 7.8 & 7.6 & 11.8 & 9.1 & 0.32 \\
\hline & & Mean & 6.5 & 6.5 & 9.5 & 7.5 & 0.34 \\
\hline \multirow[t]{3}{*}{$\mathrm{P}$} & \multirow[t]{3}{*}{$\mathrm{g} \mathrm{kg}^{-1}$} & Frederick & 1.1 & 0.7 & 1.4 & 1.1 & 0.03 \\
\hline & & Burneyville & 1.1 & 0.9 & 1.3 & 1.1 & 0.02 \\
\hline & & Mean & 1.1 & 0.8 & 1.3 & 1.1 & 0.02 \\
\hline \multirow[t]{3}{*}{ K } & \multirow[t]{3}{*}{$\mathrm{g} \mathrm{kg}^{-1}$} & Frederick & 7.5 & 4.8 & 13.4 & 8.6 & 0.40 \\
\hline & & Burneyville & 5.6 & 3.6 & 10.9 & 6.7 & 0.24 \\
\hline & & Mean & 6.6 & 4.2 & 12.2 & 7.7 & 0.29 \\
\hline \multirow[t]{3}{*}{ NDF } & \multirow[t]{3}{*}{$\mathrm{g} \mathrm{kg}^{-1}$} & Frederick & 799 & 832 & 740 & 790 & 6.0 \\
\hline & & Burneyville & 812 & 846 & 751 & 803 & 3.5 \\
\hline & & Mean & 806 & 839 & 746 & 797 & 4.2 \\
\hline \multirow[t]{3}{*}{$\mathrm{ADF}$} & \multirow[t]{3}{*}{$\mathrm{g} \mathrm{kg}^{-1}$} & Frederick & 474 & 489 & 434 & 466 & 6.0 \\
\hline & & Burneyville & 497 & 530 & 447 & 491 & 4.3 \\
\hline & & Mean & 485 & 510 & 440 & 479 & 4.1 \\
\hline \multirow[t]{3}{*}{ IVDMD $^{\mathrm{d}}$} & \multirow[t]{3}{*}{$\mathrm{g} \mathrm{kg}^{-1}$} & Frederick & 500 & 482 & 590 & 523 & 8.0 \\
\hline & & Burneyville & 456 & 413 & 551 & 467 & 4.6 \\
\hline & & Mean & 478 & 447 & 560 & 495 & 5.6 \\
\hline
\end{tabular}

a. Standard error for comparisons of means by harvest system and location $(n=48)$

b. Standard error for comparisons of location means $(n=144)$

c. Standard error for comparisons of harvest system means $(n=96)$

d. In vitro dry matter digestibility within the after seed production harvest systems from 2008 to 2009 (Table 4; 73\% to 83\% increase across locations). In contrast, biomass yield did not increase within the one harvest after frost system at Frederick and increased by only $32 \%$ at Burneyville from 2008 to 2009. Concentration of $\mathrm{N}$ in biomass within the one harvest systems also varied with years and locations. Quite unexpectedly, concentration of $\mathrm{N}$ in biomass was $52 \%$ greater within the after frost $\left(8.2 \mathrm{~g} \mathrm{~kg}^{-1}\right)$ than after seed production harvest $\left(5.4 \mathrm{~g} \mathrm{~kg}^{-1}\right)$ in 2008 at Frederick. In 2009, however, these patterns were reversed as biomass contained 2.6 and $4.7 \mathrm{~g} \mathrm{~N} \mathrm{~kg}^{-1}$ within the one har- vest after frost and one harvest after seed production systems, respectively. At Burneyville, biomass contained similar concentrations of $\mathrm{N}$ within the one harvest systems regardless of year $\left(7.7 \mathrm{~g} \mathrm{~kg}^{-1}\right)$. Harvest system effects on concentrations and removal of $\mathrm{P}$ and $\mathrm{K}$ and concentrations of NDF, ADF, and IVDMD tended to be more consistent with years and locations (Tables 4 and 5).

\section{Nitrogen fertilizer rate effects}

Nitrogen fertilizer application increased biomass yield and nutrient removal (Table 7). For 
Table 6. Biomass yield, nutrient removal rates, and nutrient concentrations of switchgrass harvested twice per year after boot stage and frost from 2008 to 2009 at Frederick and Burneyville, Oklahoma, USA

\begin{tabular}{|c|c|c|c|c|c|c|}
\hline \multirow[b]{2}{*}{ Parameter } & \multirow[b]{2}{*}{ Units } & \multirow[b]{2}{*}{ Harvest } & \multicolumn{4}{|l|}{ Location } \\
\hline & & & Frederick & Burneyville & Mean & SE \\
\hline \multirow[t]{2}{*}{ Yield } & \multirow[t]{2}{*}{$\mathrm{Mg} \mathrm{ha}^{-1}$} & Boot stage & 15.2 & 14.2 & 14.7 & $0.93^{\mathrm{a}}$ \\
\hline & & After frost & 1.7 & 4.8 & 3.3 & $0.37^{b}$ \\
\hline \multirow[t]{2}{*}{$\mathrm{N}$ removal } & \multirow[t]{2}{*}{$\mathrm{kg} \mathrm{ha}^{-1}$} & Boot stage & 106 & 161 & 134 & 7.0 \\
\hline & & After frost & 17 & 61 & 39 & 3.8 \\
\hline \multirow[t]{2}{*}{ P removal } & \multirow{2}{*}{$\mathrm{kg} \mathrm{ha}^{-1}$} & Boot stage & 21 & 20 & 20 & 0.9 \\
\hline & & After frost & 1 & 4 & 3 & 0.3 \\
\hline \multirow[t]{2}{*}{ K removal } & \multirow[t]{2}{*}{$\mathrm{kg} \mathrm{ha}^{-1}$} & Boot stage & 212 & 192 & 202 & 13.4 \\
\hline & & After frost & 9 & 22 & 15 & 1.6 \\
\hline \multirow[t]{2}{*}{$\mathrm{N}$} & \multirow[t]{2}{*}{$\mathrm{g} \mathrm{kg}^{-1}$} & Boot stage & 7.0 & 11.6 & 9.3 & 0.37 \\
\hline & & After frost & 10.7 & 12.5 & 11.6 & 0.40 \\
\hline \multirow[t]{2}{*}{$\mathrm{P}$} & \multirow[t]{2}{*}{$\mathrm{g} \mathrm{kg}^{-1}$} & Boot stage & 1.5 & 1.4 & 1.4 & 0.03 \\
\hline & & After frost & 0.8 & 0.9 & 0.9 & 0.04 \\
\hline \multirow[t]{2}{*}{ K } & \multirow[t]{2}{*}{$\mathrm{g} \mathrm{kg}^{-1}$} & Boot stage & 14.9 & 13.3 & 14.1 & 0.31 \\
\hline & & After frost & 5.5 & 4.5 & 5.0 & 0.73 \\
\hline \multirow[t]{2}{*}{$\mathrm{NDF}$} & \multirow[t]{2}{*}{$\mathrm{g} \mathrm{kg}^{-1}$} & Boot stage & 732 & 736 & 734 & 4.2 \\
\hline & & After frost & 759 & 790 & 775 & 8.8 \\
\hline \multirow[t]{2}{*}{$\mathrm{ADF}$} & \multirow[t]{2}{*}{$\mathrm{g} \mathrm{kg}^{-1}$} & Boot stage & 427 & 436 & 432 & 6.1 \\
\hline & & After frost & 442 & 472 & 459 & 4.4 \\
\hline \multirow{2}{*}{ IVDMD $^{c}$} & \multirow[t]{2}{*}{$\mathrm{g} \mathrm{kg}^{-1}$} & Boot stage & 599 & 574 & 587 & 3.6 \\
\hline & & After frost & 573 & 493 & 533 & 11.1 \\
\hline
\end{tabular}

a. Standard error for comparison of location means of boot-stage harvested biomass

b. Standard error for comparison of location means of after frost harvested biomass

c. In vitro dry matter digestibility each $\mathrm{kg}$ of $\mathrm{N}$ applied as fertilizer, biomass yield increased by 14, 17, and $39 \mathrm{~kg} \mathrm{ha}^{-1}$ within the once after seed production, once after frost, and twice per year harvest systems, respectively $(p<0.001)$. At $0 \mathrm{~kg} \mathrm{~N} \mathrm{ha}{ }^{-1}$, biomass yield was similar among the one and two harvests per year systems. Application of $180 \mathrm{~kg} \mathrm{~N}$ ha ${ }^{-1}$ maximized switchgrass yield within the two harvests per year system at $22.8 \mathrm{Mg} \mathrm{ha}^{-1}$. For each $\mathrm{kg} \mathrm{N}$ applied from 0 to $225 \mathrm{~kg} \mathrm{ha}^{-1}$, N removal increased by $0.33,0.26$, and $0.62 \mathrm{~kg} \mathrm{ha}^{-1}$ when harvested once per year after seed production, once per year after frost, and twice per year at boot stage and after frost, respectively $(p<0.001)$. Phosphorus and $\mathrm{K}$ removal rates increased by $67 \%$ to $69 \%$ on average across harvest systems as $\mathrm{N}$ rate increased from 0 to $225 \mathrm{~kg} \mathrm{ha}^{-1}$ $(p<0.001)$.

Nitrogen fertilizer application strongly increased concentration of $\mathrm{N}$ but had limited effects on concentrations of $\mathrm{P}, \mathrm{K}$, and fiber in biomass (Table 7). On average across harvest systems, locations, years, and replications, biomass $\mathrm{N}$ concentrations increased by $75 \%$ with application of 0 to $225 \mathrm{~kg} \mathrm{~N} \mathrm{ha}^{-1}(p<0.001)$. Concentrations of $\mathrm{P}$ in- creased on average from $1.0 \mathrm{~g} \mathrm{~kg}^{-1}$ at $0 \mathrm{~kg} \mathrm{~N} \mathrm{ha}^{-1}$ to $1.2 \mathrm{~g} \mathrm{~kg}^{-1}$ at $225 \mathrm{~kg} \mathrm{~N}^{-1}(p<0.001)$. Concentration of $\mathrm{K}$ increased from $7.0 \mathrm{~g} \mathrm{~kg}^{-1}$ at $0 \mathrm{~kg} \mathrm{~N} \mathrm{ha}^{-1}$ to $8.0 \mathrm{~g} \mathrm{~kg}^{-1}$ at $225 \mathrm{~kg} \mathrm{~N} \mathrm{ha}^{-1}(p<0.01)$. Neutral detergent fiber decreased by $1 \%$ and ADF increased by $2 \%$ as $\mathrm{N}$ rate increased from 0 to $225 \mathrm{~kg} \mathrm{ha}^{-1}$ $(p<0.05)$. In vitro dry matter digestibility was not affected by $\mathrm{N}$ rate, averaging $498 \mathrm{~g} \mathrm{~kg}^{-1}$ across harvest systems and $\mathrm{N}$ rates $(p=0.15)$.

Biomass yield, nutrient concentrations, and nutrient removal tended to increase with $\mathrm{N}$ fertilization rate within the after boot stage and after frost harvests of the twice-cut harvest system (Table 8). Application of $225 \mathrm{~kg} \mathrm{~N}$ ha $^{-1}$ increased biomass yield by $85 \%$ and $N$ removal by $182 \%$ within the after boot stage harvests $(p<0.001)$. Biomass yield and $\mathrm{N}$ removal rates within harvests after frost increased by $24 \%$ and $67 \%$ as $\mathrm{N}$ rate increased from 0 to $225 \mathrm{~kg} \mathrm{ha}^{-1}$. Nitrogen fertilizer application increased $\mathrm{N}$ concentrations from 6.8 to $11.6 \mathrm{~g} \mathrm{~kg}^{-1}$ within the after boot stage harvests $(p<0.001)$ and from 9.9 to $13.4 \mathrm{~g} \mathrm{~kg}^{-1}$ within regrowth harvests $(p<0.01)$. Phosphorus concentrations were not affected by $\mathrm{N}$ rate averaging $1.4 \mathrm{~g} \mathrm{~kg}^{-1}$ and $0.9 \mathrm{~g} \mathrm{~kg}^{-1}$ 
Table 7. Nitrogen fertilization rate effects on biomass yield, nutrient removal, and nutrient concentrations in switchgrass harvested once per year after seed set, once per year after frost, or twice per year after boot-stage and frost at Frederick and Burneyville, Oklahoma, USA, from 2008 to 2009

\begin{tabular}{|c|c|c|c|c|c|c|c|c|c|}
\hline \multirow[b]{2}{*}{ Parameter } & \multirow[b]{2}{*}{ Units } & \multirow[b]{2}{*}{ Harvest system } & \multicolumn{6}{|c|}{$\mathrm{N}$ fertilization rate, $\mathrm{kg} \mathrm{ha}^{-1}$} & \multirow[b]{2}{*}{ SE } \\
\hline & & & 0 & 45 & 90 & 135 & 180 & 225 & \\
\hline \multirow{3}{*}{ Yield } & \multirow{3}{*}{$\mathrm{Mg} \mathrm{ha}^{-1}$} & After seed set & 10.4 & 14.0 & 13.1 & 15.0 & 15.5 & 13.7 & \multirow[t]{3}{*}{$1.02^{\mathrm{a}}$} \\
\hline & & After frost & 10.8 & 11.7 & 13.3 & 14.4 & 13.7 & 14.6 & \\
\hline & & Twice & 12.2 & 15.5 & 18.4 & 18.0 & 22.8 & 21.0 & \\
\hline \multirow[t]{3}{*}{$\mathrm{N}$ removal } & \multirow[t]{3}{*}{$\mathrm{kg} \mathrm{ha}^{-1}$} & After seed set & 41 & 67 & 84 & 103 & 113 & 116 & \multirow[t]{3}{*}{10.8} \\
\hline & & After frost & 50 & 71 & 85 & 99 & 113 & 108 & \\
\hline & & Twice & 95 & 123 & 163 & 183 & 235 & 234 & \\
\hline \multirow[t]{3}{*}{ P removal } & \multirow[t]{3}{*}{$\mathrm{kg} \mathrm{ha}^{-1}$} & After seed set & 10 & 14 & 15 & 16 & 18 & 16 & \multirow[t]{3}{*}{1.2} \\
\hline & & After frost & 8 & 9 & 11 & 13 & 12 & 13 & \\
\hline & & Twice & 16 & 20 & 24 & 24 & 29 & 28 & \\
\hline \multirow{3}{*}{ K removal } & \multirow[t]{3}{*}{$\mathrm{kg} \mathrm{ha}^{-1}$} & After seed set & 70 & 88 & 95 & 96 & 105 & 96 & \multirow[t]{3}{*}{11.6} \\
\hline & & After frost & 39 & 51 & 57 & 66 & 52 & 66 & \\
\hline & & Twice & 136 & 176 & 226 & 226 & 284 & 255 & \\
\hline \multirow[t]{3}{*}{$\mathrm{N}$} & \multirow{3}{*}{$\mathrm{g} \mathrm{kg}^{-1}$} & After seed set & 4.1 & 4.9 & 6.5 & 7.2 & 7.6 & 8.4 & \multirow[t]{3}{*}{0.50} \\
\hline & & After frost & 4.3 & 6.1 & 6.2 & 6.9 & 8.2 & 7.4 & \\
\hline & & Twice & 7.3 & 7.8 & 9.1 & 10.6 & 10.7 & 11.7 & \\
\hline \multirow[t]{3}{*}{$\mathrm{P}$} & \multirow[t]{3}{*}{$\mathrm{g} \mathrm{kg}^{-1}$} & After seed set & 1.0 & 1.0 & 1.1 & 1.1 & 1.1 & 1.2 & \multirow[t]{3}{*}{0.04} \\
\hline & & After frost & 0.7 & 0.7 & 0.8 & 0.9 & 0.9 & 0.9 & \\
\hline & & Twice & 1.3 & 1.3 & 1.3 & 1.4 & 1.3 & 1.4 & \\
\hline \multirow[t]{3}{*}{ K } & \multirow[t]{3}{*}{$\mathrm{g} \mathrm{kg}^{-1}$} & After seed set & 6.6 & 6.1 & 7.0 & 6.2 & 6.6 & 6.8 & \multirow[t]{3}{*}{0.42} \\
\hline & & After frost & 3.4 & 4.3 & 4.3 & 4.6 & 3.9 & 4.5 & \\
\hline & & Twice & 11.1 & 11.5 & 12.5 & 12.6 & 12.7 & 12.7 & \\
\hline \multirow[t]{3}{*}{ NDF } & \multirow[t]{3}{*}{$\mathrm{g} \mathrm{kg}^{-1}$} & After seed set & 807 & 813 & 802 & 808 & 806 & 797 & 5.7 \\
\hline & & After frost & 854 & 841 & 840 & 830 & 834 & 832 & \\
\hline & & Twice & 739 & 749 & 748 & 744 & 750 & 743 & \\
\hline $\mathrm{ADF}$ & $\mathrm{g} \mathrm{kg}^{-1}$ & After seed set & 475 & 480 & 481 & 490 & 493 & 490 & 5.8 \\
\hline & & After frost & 510 & 503 & 509 & 511 & 514 & 510 & \\
\hline & & Twice & 430 & 433 & 440 & 441 & 452 & 446 & \\
\hline IVDMD $^{b}$ & $\mathrm{~g} \mathrm{~kg}^{-1}$ & After seed set & 479 & 473 & 485 & 477 & 471 & 483 & 7.7 \\
\hline & & After frost & 434 & 451 & 456 & 448 & 447 & 447 & \\
\hline & & Twice & 569 & 566 & 571 & 574 & 567 & 578 & \\
\hline
\end{tabular}

a. Standard error for comparison of means by $\mathrm{N}$ fertilizer rate and harvest system among harvest systems $(n=16)$

b. In vitro dry matter digestibility

within the after boot stage and after frost harvests. Phosphorus removal, however, increased within both harvests with $\mathrm{N}$ fertilization rate. Concentration and removal of $\mathrm{K}$ increased by $11 \%$ and $93 \%$, respectively, within the after boot stage harvests but were unaffected by $\mathrm{N}$ rate within the after frost harvests. Concentrations of NDF and ADF increased with $\mathrm{N}$ rate within the after boot stage harvest but were unaffected by $\mathrm{N}$ rate within the after frost harvests. In vitro dry matter digestibility was unaffected by $\mathrm{N}$ rate within either the after boot stage or after frost harvests $(p>0.10)$.

\section{Discussion}

Few studies have simultaneously documented the impacts of harvest system and $\mathrm{N}$ fertilizer rate on switchgrass biomass yield, nutrient composition, and nutrient removal rates. We found that biomass yields of Alamo switchgrass, a southern lowland type, were similar among once after seed set, once after frost, and two harvests per year systems when $\mathrm{N}$ fertilizer rates were $0 \mathrm{~kg} \mathrm{ha}^{-1}$. Benefits of harvesting switchgrass twice per year were realized as $\mathrm{N}$ fertilizer rates increased (Tables 7 and 8). Sand- 
Table 8. Nitrogen fertilizer rate effects on biomass yield, nutrient removal, and nutrient composition in switchgrass harvested twice per year after boot stage and frost at Frederick and Burneyville, Oklahoma, USA, from 2008-2009

\begin{tabular}{|c|c|c|c|c|c|c|c|c|}
\hline \multirow[b]{2}{*}{ Parameter } & \multirow[b]{2}{*}{ Harvest period } & \multicolumn{6}{|c|}{ Nitrogen fertilization rate, $\mathrm{kg} \mathrm{ha}^{-1}$} & \multirow[b]{2}{*}{ SE } \\
\hline & & 0 & 45 & 90 & 135 & 180 & 225 & \\
\hline & & \multicolumn{7}{|c|}{$\mathrm{Mg} \mathrm{ha}^{-1}$} \\
\hline \multirow[t]{3}{*}{ Biomass yield } & Boot stage & 9.4 & 12.7 & 15.2 & 14.9 & 18.7 & 17.4 & $1.10^{\mathrm{a}}$ \\
\hline & After frost & 2.9 & 2.8 & 3.2 & 3.1 & 4.1 & 3.6 & $0.34^{\mathrm{b}}$ \\
\hline & & \multicolumn{7}{|c|}{$\mathrm{kg} \mathrm{ha}^{-1}$} \\
\hline \multirow[t]{2}{*}{$\mathrm{N}$ removal } & Boot stage & 66 & 94 & 128 & 145 & 182 & 186 & 12.4 \\
\hline & After frost & 29 & 29 & 35 & 39 & 52 & 49 & 3.8 \\
\hline \multirow[t]{2}{*}{ P removal } & Boot stage & 13 & 17 & 21 & 22 & 25 & 25 & 1.5 \\
\hline & After frost & 3 & 2 & 3 & 3 & 4 & 3 & 0.3 \\
\hline \multirow[t]{3}{*}{ K removal } & Boot stage & 123 & 165 & 210 & 212 & 263 & 238 & 16.8 \\
\hline & After frost & 13 & 11 & 16 & 14 & 21 & 17 & 2.2 \\
\hline & & $\mathrm{g} \mathrm{kg}$ & & & & & & \\
\hline \multirow[t]{2}{*}{$\mathrm{N}$} & Boot stage & 6.8 & 7.5 & 9.1 & 10.5 & 10.6 & 11.6 & 0.53 \\
\hline & After frost & 9.9 & 10.1 & 10.7 & 12.8 & 12.8 & 13.4 & 0.52 \\
\hline \multirow[t]{2}{*}{$\mathrm{P}$} & Boot stage & 1.4 & 1.4 & 1.5 & 1.5 & 1.4 & 1.5 & 0.04 \\
\hline & After frost & 0.9 & 0.8 & 0.9 & 0.9 & 0.9 & 10.0 & 0.04 \\
\hline \multirow[t]{2}{*}{ K } & Boot stage & 13.2 & 13.3 & 14.5 & 14.8 & 14.6 & 14.7 & 0.51 \\
\hline & After frost & 6.3 & 4.5 & 4.9 & 4.4 & 5.0 & 4.9 & 0.78 \\
\hline \multirow[t]{2}{*}{ NDF } & Boot stage & 721 & 738 & 738 & 733 & 741 & 732 & 6.2 \\
\hline & After frost & 777 & 784 & 777 & 770 & 770 & 769 & 7.5 \\
\hline \multirow[t]{2}{*}{$\mathrm{ADF}$} & Boot stage & 417 & 424 & 432 & 433 & 445 & 439 & 6.8 \\
\hline & After frost & 461 & 461 & 459 & 455 & 456 & 453 & 4.3 \\
\hline \multirow[t]{2}{*}{ IVDMD $^{c}$} & Boot stage & 587 & 579 & 586 & 591 & 582 & 594 & 6.7 \\
\hline & After frost & 536 & 527 & 528 & 534 & 536 & 538 & 9.7 \\
\hline
\end{tabular}

a. Standard error for comparison of $\mathrm{N}$ fertilizer rate means in after boot stage harvested switchgrass $(n=16)$

b. Standard error for comparison of $\mathrm{N}$ fertilizer rate means in switchgrass regrowth harvested after frost $(n=16)$

c. In vitro dry matter digestibility erson et al. (1999) did not observe benefits of harvesting switchgrass twice per year for biomass yield and found a biomass yield loss when harvests were delayed from September to November with Alamo switchgrass fertilized at 67 and $134 \mathrm{~kg} \mathrm{~N}^{-1}$ in north-central Texas. Vogel et al. (2002) observed that harvest treatment and $\mathrm{N}$ fertilizer rate effects on Cave-in-Rock, a southern upland type, were independent in research in Nebraska and Iowa. In these northern environments, harvesting switchgrass once per year during reproductive stages maximized biomass yields (Vogel et al. 2002). Research in eastern Canada found that biomass yields of the switchgrass cultivars Cave-in-Rock, Pathfinder, and Sunburst also were related to physiological maturation time (Madakadze et al. 1999).

Whether switchgrass stands managed with low$\mathrm{N}$ inputs should be harvested once per year after seed set (October) or once per year after frost (December) in this region may depend on the biomass to ethanol conversion process and risks associated with allowing stands to remain in the field (Adler et al. 2006). Harvest of switchgrass after frost produced feedstock material with the lowest concentrations of $\mathrm{P}$ and $\mathrm{K}$ and highest concentrations of NDF and ADF. Although concentrations of cellulose and hemicellulose were greatest within the after frost harvests, cross linkages of these components with lignin may reduce their availability and overall ethanol yields in a fermentation process (Adler et al. 2006; Lemus et al. 2008a). In contrast to research by Sanderson et al. (1999) and Vogel et al. (2002), we did not observe a difference in average $\mathrm{N}$ concentrations in biomass between harvests after seed set and harvests after frost.

Strong precipitation differences among years caused variability in harvest times, biomass yields, and nutrient concentrations. Favorable precipitation and mild temperatures throughout autumn may have enabled greater biomass within the once 
after frost compared to the once after seed harvest in 2008. Although total precipitation was lower than long-term averages in 2008, 9 and $15 \mathrm{~cm}$ of precipitation fell in August at Burneyville and Frederick, respectively. Daily temperatures averaged $22^{\circ} \mathrm{C}$ across August, September, and October at both locations, favorable temperatures for switchgrass growth (Hsu et al. 1985). Although biomass yields strongly increased from the second to third growing seasons, we were unable to separate out the effects of greater stand development with those of the greater precipitation from 2008 to 2009.

Location effects on biomass yields and nutrient concentrations were due in part to differences in total rainfall, rainfall effects on harvest times, and inherent soil physical and chemical characteristics. Although biomass yields on average were similar among the two locations despite precipitation differences, Burneyville had greater ability to respond with regrowth following the first harvest. Greater biomass yields within the after seed set harvest at Frederick (Table 4), due to a harvest one month after the seed set harvest at Burneyville, also contributed to similar biomass yields on average across locations. Although lower in soil organic matter and presumed to be lower in water holding capacity, the sandy loam soils at Burneyville historically supported tall $\mathrm{C}_{4}$ grasses, and thus would be quite suitable for production of switchgrass as a biomass energy crop. Silt loam soils at Frederick also historically supported tall, native $\mathrm{C} 4$ grasses despite less precipitation. Simulation models have found biomass yields in the Great Plains to be most sensitive to season duration, soil water, and soil N (Kinery et al. 2008).

Although there is potential to increase biomass yields through $\mathrm{N}$ fertilizer application and harvesting twice per year, greater mineral nutrient concentrations may reduce the quality of biomass as cellulosic feedstocks. Greater concentration and removal of nutrients in biomass also would significantly increase fertilization requirements and harvesting costs. Nonetheless, the ability to increase total supply of biomass to cellulosic biorefineries on a yearround basis may justify use of this harvest system. Harvest of switchgrass after boot stage, although not optimum for biofuels quality, may provide a source of biomass during mid-summer and minimize storage needs of biomass material harvested from the previous year. Positive effects of two harvests over that of one harvest per year systems on total biomass yields have been observed in other studies where $\mathrm{N}$ fertilizer was applied and precipitation and temperatures were adequate to support regrowth following the mid-summer harvest (Sanderson et al. 1999; Vogel et al. 2002; Fike et al. 2006b).

Although harvest of switchgrass twice per year increased mineral nutrient concentrations, improved dry matter digestibility, and reduced fiber concentrations, the biomass was generally of poor quality for livestock. Boot-stage is often considered a time period at which to balance forage production and quality in forage grasses (Ball et al. 2001). At this stage, we found the harvested biomass to be $5.8 \%$ crude protein, $73.4 \% \mathrm{NDF}$, and $58.7 \%$ digestible dry matter on average across locations (Table 3). Crude protein concentrations below $7 \%$ of dry matter limit ruminal fermentation of forages and do not meet minimal protein requirements of growing animals (Burns et al. 1984). Intake of forage also may be restricted at such high NDF concentrations (Ball et al. 2001). Switchgrass harvested at boot stage or later in the year may thus have value only as a roughage source for maintenance of beef cows (Burns et al. 1984). Optimizing forage quality of switchgrass would require utilization earlier in the season at a vegetative stage. Harvesting or grazing when switchgrass was at $30-\mathrm{cm}$ height in May and allowing regrowth to accumulate from there on would improve utility of switchgrass as a forage.

Nitrogen rate responses were comparable to other research findings on switchgrass in the southern USA. Application of $168 \mathrm{~kg} \mathrm{~N} \mathrm{ha}^{-1}$ produced biomass yields of 10.7 to $14.5 \mathrm{Mg} \mathrm{ha}^{-1}$ across 3 to 6 years of research on Alamo in single, late-summer harvest systems in Texas (Muir et al. 2001). These authors also reported a maximum yield of $22.5 \mathrm{Mg} \mathrm{ha}^{-1}$ with $168 \mathrm{~kg} \mathrm{ha}^{-1}$ during one year of their study. In our study biomass yields varied from 10.4 to $15.5 \mathrm{Mg} \mathrm{ha}^{-1}$ and 10.8 to $14.6 \mathrm{Mg} \mathrm{ha}^{-1}$ within the one harvest after seed set and one harvest after frost harvest systems as $\mathrm{N}$ rate ranged from 0 to $225 \mathrm{~kg} \mathrm{ha}^{-1}$, respectively. We also found that biomass yields were maximized at $22.8 \mathrm{Mg} \mathrm{ha}^{-1}$ with application of $180 \mathrm{~kg} \mathrm{~N} \mathrm{ha}^{-1}$ within the two harvests per year system. Research on $>5$-yr old stands of switchgrass in the upper southeastern USA has found that switchgrass managed under multiple cut systems have higher $\mathrm{N}$ fertilization requirements because 
of greater $\mathrm{N}$ removal during mid-summer harvests (Fike et al. 2006a). Ma et al. (2001) reported average biomass yields of $12.0 \mathrm{Mg}^{-1}$ with $224 \mathrm{~kg} \mathrm{~N} \mathrm{ha}^{-1}$ on 3-yr old stands of Alamo switchgrass in Alabama. Cassida et al. (2005) found that yield and persistence of switchgrass was lower for upland than lowland genotypes, and that lowland varieties such as Alamo yielded close to $15.0 \mathrm{Mg} \mathrm{ha}^{-1}$ under one harvest per year systems across sites in Texas, Arkansas, and Louisiana.

Biomass yield responses to $\mathrm{N}$ rate were greater than that observed with switchgrass in northern USA locations. Vogel et al. (2002) reported that optimum biomass yields of Cave-in-Rock switchgrass, a southern upland variety, were obtained with lower rates of $\mathrm{N}$ in research in Nebraska and Iowa. Application of $120 \mathrm{~kg} \mathrm{~N} \mathrm{ha}^{-1}$ produced yields ranging from 10.5 to $11.2 \mathrm{Mg}^{-1}$ in Nebraska and 11.6 to $12.6 \mathrm{Mg} \mathrm{ha}^{-1}$ in Iowa for single, reproductive stage harvests (Vogel et al. 2002). Biomass yields of switchgrass-dominated Conservation Reserve Program (CRP) land in eastern South Dakota responded to $\mathrm{N}$ applications up to $112 \mathrm{~kg} \mathrm{ha}^{-1}$ (Mulkey et al. 2006). Ten-yr old stands of CRP dominated by Cave-in-Rock switchgrass increased from 3.9 to $5.2 \mathrm{Mg} \mathrm{ha}^{-1}$ with 0 to $224 \mathrm{~kg} \mathrm{~N} \mathrm{ha}^{-1}$ in Iowa (Lemus et al. 2008a).

The higher $\mathrm{N}, \mathrm{P}$, and $\mathrm{K}$ removal with the twocut system relative to one-cut systems resulted from greater concentrations of nutrients in aboveground tissues during the boot stage harvests and overall greater biomass yields achieved by harvesting twice per year. We attribute reduced concentrations and removal of $\mathrm{P}$ and $\mathrm{K}$ within harvests after frost compared to after boot stage and after seed set harvests to plants being fully senesced and greater translocation of nutrients to roots as harvests are delayed (Adler et al. 2006). Although there was variability among locations and years, we do not observe greater translocation of $\mathrm{N}$ within once after frost than within once after seed set harvests, suggesting that translocation of $\mathrm{N}$ to belowground reserves had occurred between the onset of reproduction and seed set. Phosphorus and K translocation continued after seed set through the killing frost.

Overall the amount of $\mathrm{N}, \mathrm{P}$, and $\mathrm{K}$ removed among the harvest systems were greater than those reported for switchgrass by other researchers. Lemus et al. (2008 b) reported $\mathrm{N}$ removal rates ranging from 94 to $176 \mathrm{~kg} \mathrm{ha}^{-1}$ with application of 0 to
$270 \mathrm{~kg} \mathrm{~N} \mathrm{ha}^{-1}$ under two harvests per year systems in Virginia. Research in Tennessee found $\mathrm{N}$ removal rates ranging from 37 to $65 \mathrm{~kg} \mathrm{ha}^{-1}$ and 101 to $125 \mathrm{~kg} \mathrm{ha}^{-1}$ under one and two harvest per year systems, respectively (Reynolds et al. 2000). Differences in age of switchgrass stands, cultivars used, residual soil $\mathrm{N}$ availability, tissue $\mathrm{N}$ concentrations, and overall biomass yields may have contributed to variability among these studies. Continuous harvesting and removal of biomass from agricultural systems without nutrient replacement has the potential to mine soil of nutrients and impact longterm productivity of feedstocks (Fixen 2007).

\section{Conclusions}

Nitrogen fertilizer application will be necessary to attain highest biomass yields of young stands of switchgrass in the southern Great Plains. Biomass yields during these first two years of production in Oklahoma, USA, were maximized with $\mathrm{N}$ rates of 135 to $180 \mathrm{~kg} \mathrm{ha}^{-1}$. Greater nutrient removal rates in switchgrass harvested twice per year would necessitate higher rates of $\mathrm{N}, \mathrm{P}$, and $\mathrm{K}$ fertilization than one harvest per year systems. Given that a substantial amount of $\mathrm{P}$ and $\mathrm{K}$ are removed in biomass harvests, periodic analysis of soil should be undertaken in switchgrass production sites to detect development of nutrient deficiencies. Harvesting once per year after seed set or after frost produces smaller biomass yields, but it reduces biomass mineral nutrient concentrations and soil nutrient removal in this environment. Harvesting switchgrass twice per year after boot stage and after frost, although it produced the greatest biomass yields, did not produce high quality forage, as we had hypothesized. Thus, livestock producers hoping to incorporate switchgrass into their operations will find it necessary to utilize switchgrass during spring to early summer when switchgrass is in a vegetative stage. Allowing switchgrass to regrow for biofuel purposes after early summer utilization would allow for dual-purpose use of this crop if rainfall is sufficient.

Acknowledgments - We thank Ceres, Inc. for their support of this research. Critical reviews of research procedures and results were provided by Cory Christenson, Jeff Gwyn, Bud Wylie, Joe Bouton, Steve Rhines, Twain Butler, and John Blanton. The Samuel Roberts Noble Foundation personnel contributing to the successful completion of this research included Shawn Norton, Tabby Campbell, Julie Barrick, Derrick Warren, Kevin Lynch, and Roger Hartwell. 


\section{References}

Adler PR, Sanderson MA, Boateng AA, Weimer PJ, Jung HG (2006) Biomass yield and biofuel quality of switchgrass harvested in fall or spring. Agron J 98:1518-1525

Ball DM, Collins M, Lacefield GD, Martin NP, Mertens DA, Olson KE, Putnam DH, Undersander DJ, Wolf MW (2001) Understanding forage quality. American Farm Bureau Federation Publication 1-01, Park Ridge, Illinois

Biomass Research and Development Board (2008) National Biofuels Action Plan. Biomass Research and Development Board. http://www.brdisolutions.com/default.aspx Accessed 30 Oct 2009

Bransby DI, Samson R, Parrish DJ, Fike JH (2008) Harvest and conversion systems for producing energy from switchgrass: Logistic and economic considerations. Forage and Grazinglands. doi:10.1094/FG-2008-0722-01-RV

Burns JC, Mochrie RD, Timothy DH (1984) Steer performance from two perennial Pennisetum species, switchgrass, and a fescue-'Coastal' bermudagrass system. Agron J 76:795-800

Cassida KA, Muir JP, Hussey MA, Read JC, Venuto BC, Ocumpaugh WR (2005) Biomass yield and stand characteristics of switchgrass in south central U.S. environments. Crop Sci 45:673-681

CAST (2007) Convergence of agriculture and energy: II. Producing cellulosic biomass for biofuels. CAST Commentary QTA2007-2. Council for Agricultural Science and Technology, Ames, Iowa

Farrell AE, Plevin RJ, Turner BT, Jones AD, O'Hare M, Kammen DM (2006) Ethanol can contribute to energy and environmental goals. Sci 311:506-508

Fike JH, Parrish DJ, Wolf DD, Balasko JA, Green JT Jr, Rasnake M, Reynolds JH (2006a) Long term yield potential of switchgrass-for-biofuel systems. Biomass Bioenergy 30:198-206

Fike JH, Parrish DJ, Wolf DD, Balasko JA, Green JT Jr, Rasnake M, Reynolds JH (2006b) Switchgrass production for the upper southeastern USA: influence of cultivar and cutting frequency on biomass yields. Biomass Bioenergy 30:207-213

Fixen PE (2007) Potential biofuels influence on nutrient use and removal in the U.S. Better Crops 91:12-14

Fixen PE, Grove JH (1990) Testing soils for phosphorus. In: Westerman RL (ed) Soil testing and plant analysis, 3rd edn. ASA-CSSA-SSSA, Madison, pp 141-180

Haby VA, Russelle MP, Skogley EO (1990) Testing soils for potassium, calcium, and magnesium. In: Westerman RL (ed) Soil testing and plant analysis, 3rd edn. ASA-CSSASSSA, Madison, pp 181-228

Hsu FH, Nelson CJ, Matches AG (1985) Temperature effects on seedling development of perennial warm-season forage grasses. Crop Sci 25:249-255

Kinery JR, Schmer MR, Vogel KP, Mitchell RB (2008) Switchgrass biomass simulation at diverse sites in the northern Great Plains of the U.S. Bioenergy Res 1:259-264

Lemus R, Brummer EC, Burras CL, Moore KJ, Barker MF, Molstad NE (2008a) Effects of nitrogen fertilization on biomass yield and quality in large fields of established switchgrass in southern Iowa, USA. Biomass Bioenergy 32:1187-1194
Lemus R, Parrish DJ, Abaye O (2008b) Nitrogen-use dynamics in switchgrass grown for biomass. Bioenergy Res $1: 153-162$

Lierop WV (1990) Soil pH and lime requirement determination. In: Westerman RL (ed) Soil testing and plant analysis, 3rd edn. ASA-CSSA-SSSA, Madison, pp 73-126

Ma Z, Wood CW, Bransby DI (2001) Impact of row spacing, nitrogen rate, and time on carbon partitioning of switchgrass. Biomass Bioenergy 20:413-419

Madakadze IC, Stewart K, Peterson PR, Coulman BE, Smith DL (1999) Switchgrass biomass and chemical composition for biofuel in eastern Canada. Agron J 91:696-701

McLaughlin SB, Kszos LA (2005) Development of switchgrass (Panicum virgatum) as a bioenergy feedstock in the United States. Biomass Bioenergy 28:515-535

Muir JP, Sanderson MA, Ocumpaugh WR, Jones RM, Reed RL (2001) Biomass production of 'Alamo' switchgrass in response to nitrogen, phosphorus, and row spacing. Agron J 93:896-901

Mulkey VR, Owens VN, Lee DK (2006) Management of switchgrass-dominated Conservation Reserve Program lands for biomass production in South Dakota. Crop Sci 46:712-720

Nelson DW, Sommers LE (1982) Total carbon, organic carbon and organic matter. In: Page AL (ed) Methods of soil analysis. Part 2-chemical and microbiological properties, 2nd edn. ASA-CSSA-SSSA, Madison

Oklahoma Climatological Survey (2009) http://climate.mesonet.org/county climate/Products/Choose By County Page.html Accessed 30 Oct 2009

Parrish DJ, Fike JH, Bransby DI, Samson R (2008) Establishing and managing switchgrass as an energy crop. Forage and Grazinglands. doi:10.1094/FG-2008-0220-01-RV

Reynolds JH, Walker CL, Kirchner MJ (2000) Nitrogen removal in switchgrass biomass under two harvest systems. Biomass Bioenergy 19:281-286

Sanderson MA, Read JC, Reed RL (1999) Harvest management of switchgrass for biomass feedstock and forage production. Agron J 91:5-10

Sanderson MA, Martin NP, Adler P (2007) Biomass, energy, and industrial uses of forages. In: Barnes RF et al (eds) Forages. The science of grassland agriculture, vol II, 6th edn. Blackwell, Ames, pp 635-647

Schmer MR, Vogel KP, Mitchell RB, Perrin RK (2008) Net energy of cellulosic ethanol from switchgrass. Proc Nat Acad Sci 105:464-469

Shenk JS, Westerhaus MO (1994) The application of near infrared reflectance spectroscopy (NIRS) to forage analysis. In: Fahey GC (ed) Forage quality, evaluation, and utilization. ASA-CSSA-SSSA, Madison, pp 406-449

USDA-NASS (2008) Agricultural statistics 2008. United States Government Printing Office, Washington D.C. http://www.nass.usda.gov/Publications/Ag_Statistics/2008/2008.pdf Accessed 30 Oct 2009

Varvel GE, Vogel KP, Mitchell RB, Follett RF, Kimble JM (2008) Comparison of corn and switchgrass on marginal soils for bioenergy. Biomass Bioenergy 32:18-21

Vogel KP, Brejda JJ, Walters DT, Buxton DR (2002) Switchgrass biomass production in the Midwest USA: harvest and nitrogen management. Agron J 94:413-420 